\title{
Pecularities of the lithology and fauna of the early Katian (Ordovician) in the Lithuanian facies zone
}

\author{
Juozas Paškevičius \\ Vilnius University, \\ Department of Geology and Mineralogy, \\ M. K. Čiurlionio St. 21, \\ LT-03101 Vilnius, Lithuania \\ E-mail juozas.paskevicius@gf.vu.lt
}

Paškevičius J. Pecularities of the lithology and fauna of the early Katian (Ordovician) in the Lithuanian facies zone. Geologija. Geografija. 2016. T. 2(2). ISSN 2351-7549.

The lithology and fauna on the south-eastern slope of the Middle Lithuanian Depression within the Lithuanian facies zone (belt) is discussed in the present paper. The study material consists of core from two deep drill-holes: Taučionys- 49 and Drūkšiai-6 (Kazimirovo). As a result Drūkšiai, Dysna, Jakšiai, Paekna and Kaimynai formations from the Oandu and Nabala regional stages have been distinguished in the studied lithostratigraphy. The biostratigraphy of described formations is based on the description of brachiopods, trilobites and ostracodes. A stratigraphic gap distinguished in the Estonian Oandu Regional Stage in the stratotype section is completed by the continuous parastratotypic section of the Lithuanian Pajavonys-13 well. It is shown that the attribution by Sidaravičiene (1996) of Paekna, Kaimynai, and Dobilyne formations in the Drūkšiai area to the Vormsi Regional Stage should be corrected. Only the Dobilyne Regional Stage should be left in this regional stage. The study presents new correlation between Middle Lithuanian and Livonian facies (belt) zones. The Drūkšiai-Paekna and the Kaimynai formations are respectively correlated with the clingani and linearis graptolite zones. A new species of brachiopods - Thaerodonta notabile Pašk. sp. nov. - is described.

Key words: Lithuanian facies zone, Ordovician, Katian, lithostratigraphy, correlation, brachiopods

\section{INTRODUCTION}

Previously, the lithology and fauna in the Lithuanian Ordovician facies zone during the early Katian Stage had been distinguished in the axial part and the south-eastern slope of the Middle Lithuanian Depression (Paškevičius, 1958; Laškov, Paškevičius, 1991). The axial part is dominated by marl and argillaceous limestone rocks, especially with abundant, often thin-walled fauna of brachiopods, and on the southeast slope - limestone, marls and, to a lesser extent, clayey limestone with the predominance of brachiopods with intermediate shell thicknesses (Paškevičius, 2000). The centreline of the trough passes through the drillhole locations Vištytis-17, Mažosios Lapès-106, between Ukmergè-10 and Krekenava-7, east of Butkūnai-241 and through Ludza-15. The southeastern slope of the trough is the area of the study in this paper (Fig. 1).

One of the most important features is the change in lithology of the rocks. The axis of the deflection contains clayey-carbonate sediments (calcareous clay, marl, and clayey limestone) developed, while the south-eastern slope is dominated by the limestones (nodular, biomorphic, chemogenic limestone with marl interlayering). The change in lithology shows the changes in thicknesses of beds. The axial part of the depression during the Oandu, Rakvere and Nabala time is notable for greatly increased thickness of the rocks. While the southeastern slope of the structure is distinguished by 


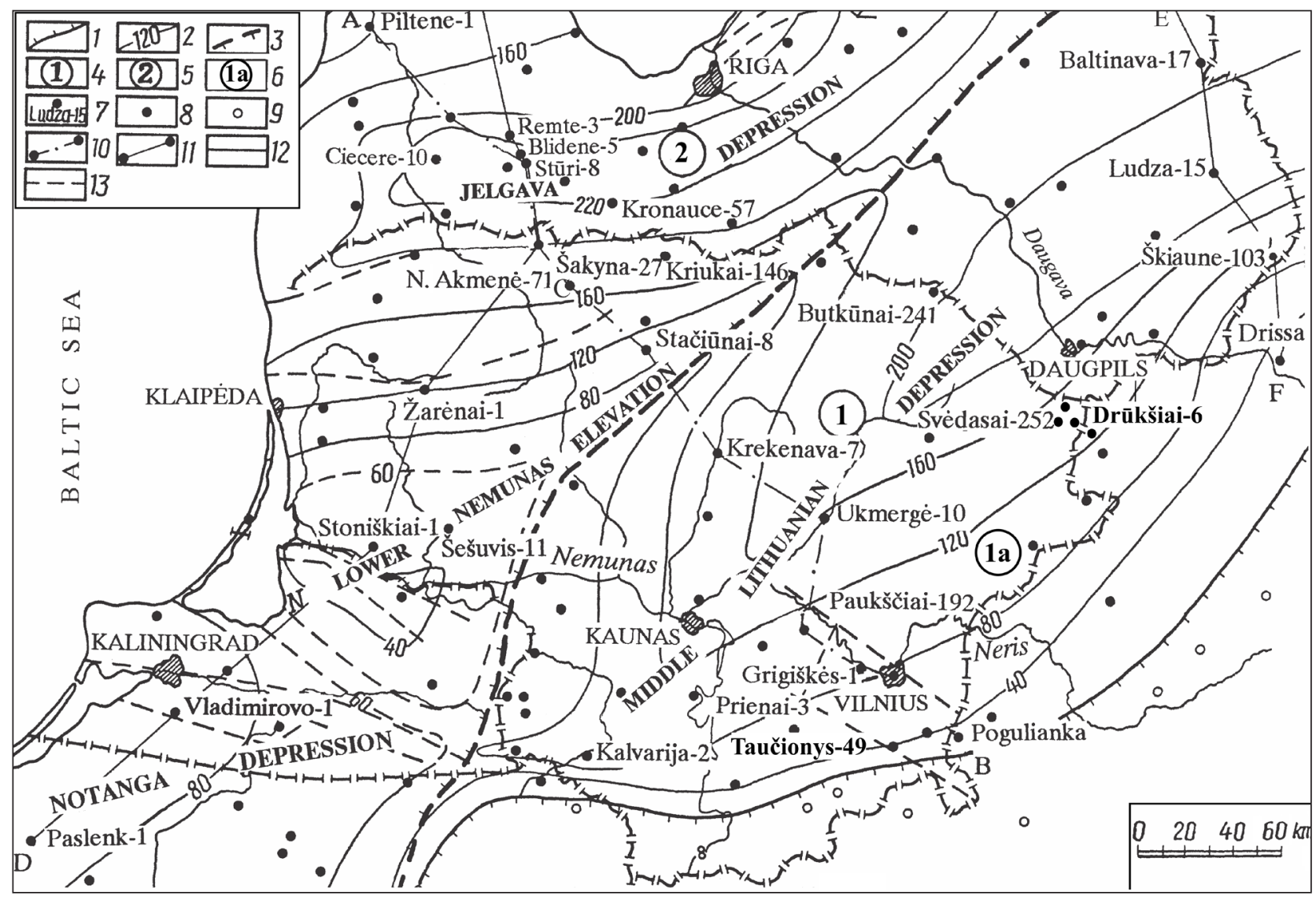

Fig. 1. Distribution of Ordovician rocks, their thickness, structural and facial zonation in Lithuania. 1 - denudation boundary of Ordovician rocks, 2 - isopachs, m of Ordovician beds, 3 - structural-facial boundary, 4 - Lithuanian facial zone, 5 - Livonian facial zone, 6 - slope of the south-eastern Middle Lithuanian Depression, 7 - stratotypes and other major boreholes, 8 - boreholes drilled through Ordovician beds, 9 - boreholes without Ordovician beds, 10 - line of the facial section (Piltene-Vilnius), 11 - line of the paleogeological sections, 12 - tectonic faults, 13 - tectonic faults supposed

reduced thicknesses of rocks at the time discussed (drill-holes: Vilkiškès-68, Ilgai-54, Taučionys-49, Drūkšiai-6 and others). Apparently, this reduced thickness is due to its location in the proximal part of the basin, where it had been influenced by the development of a lift-slope of the BelarussianMazurian Anteclise (Paškevičius, 1973).

The above-mentioned rocks are also notable for buried benthic fauna that is rather rich and mainly composed of brachiopods, trilobites and, to a lesser extent, bryozoans and other well-preserved fauna groups. It developed on the soft as well as hard bottom conditions of the basins. The withering of the fauna occurred at the intervals of increased carbonate and clayey-carbonate sedimentations: in the first case, the abundant fauna was found in marls, while in the second case, due to weak carbonate particle sedimentation and changing conditions, mass death events of fauna created biomorphic limestone interbeds, especially during the Oandu and Rakvere stages. The shells of brachiopods generally are not destroyed, though partially damaged. This reveals slow current activities of warm waters of a shallow water body under conditions of sufficient bottom aeration (Musteikis, Paškevičius, 1999).

\section{METHODS}

Deep holes in south-eastern Lithuania were drilled during the geological expeditions of the searchparty of the Geological Board of the Lithuanian SSR in 1961 and the Geological Survey of Lithuania in 1993. The present article deals with the following drill-holes: Taučionys -49 described by a geologist A. Šliaupa (Report by Vaitonis, Šliaupa et al., 1962) and Drūkšiai (Kazimirovo)-6 described by Laškov and Marcinkevičius (1995). The core material 
of the Ordovician and Silurian drill-holes was studied by J. Paškevičius. He amassed a collection of fauna of these drill-holes. Mineralogical, petrographic and chemical composition of the sediments in the cores was determined at the laboratory of the Geological Survey of Lithuania.

The collected fauna samples were treated with a solution of hydrogen peroxide $\left(\mathrm{H}_{2} \mathrm{O}_{2}\right)$ that released the valves of brachiopods from marls and limestones. Part of the collected fauna of brachiopods was studied by applying rock mechanical preparation together with hydrogen peroxide digestion. With the predominance of low hardness of marl-rich rocks, such technique was successful for the extraction of brachiopods. The marls were typified according to well-developed thin-walled brachiopods (plectambonites, strophomenids), which lived on the soft bottom substrates. Brachiopods with normally thick walls (orthids, platystrophia) occurred in the limestones and marls.

Identification of brachiopods and trilobites in the sections of the Taučionis-49 drill-hole was done by the author in 1961. His identifications were supported by an Estonian expert of the Ordovician R. M. Männil in 1964. In the most cases, he agreed on the correctness of the recognition of the specified fauna. The collection and identification of the fauna of the Drūkšiai-6 drill-hole was accomplished by the author. The ostracodes were studied by Sidaravičienè (1992).

Based on the study of the rich fauna of brachiopods, ostracodes, and some trilobites, as well as lithological composition of rocks, the stratigraphic distinction of these sections was established.

\section{LITHOSTRATIGRAPHY}

The lithostratigraphy of the early Katian Stage rocks studied is fully represented in the context of SLE Drūkšiai-6. The distinguished lithostratigraphic units are based on the description of drill cores, study of mineralogy and petrography, and chemical composition of the rocks, as well as the definition of brachiopods, ostracodes and trilobites. The present study is focussed on the Drükšiai, Dysna, Jakšiai, Paekna and Kaimynai formations (Fig. 2). The determination of their ages is based on the affinities of the fauna.

The Drūkšiai Formation of the Oandu Stage is represented by alternating limestone and marl at a ratio of 6:4. Limestones in the Drūkšiai- 6 well are at a depth interval of 388.6-387.7. The limestone is gray, biomorphic, not clearly layered, and aphanitic in the upper part (7 $\mathrm{cm}$ in thickness). There are fragments of rounded limestone fragments and pyritised fauna at the base of the limestone bed. Marl clay is green slaty. The thicknesses of limestone and marl lamina is 5-7 and $2-9 \mathrm{~cm}$, correspondingly. The lamination is horizontal. The strata boundaries are sharp. The limestone in the lower part of the bed at its lower end $(8 \mathrm{~cm})$ is a conglomerate consisting of semi-rounded, angular fragments of limestone, sized up to $2.5 \mathrm{~cm}$ in the long axis, which are pyritised. Fragments of the conglomerate take up about $55-60 \%$ of the rock. The cement consists of small fragments of organogenic, detrital fraction and recrystallised yellowish-gray calcite (basal conglomerate). It is situated at a depth interval from 387.2 to $387.0 \mathrm{~m}$ on an uneven surface of the Vilučiai Formation of the Keila Regional Stage with many burrows up to $5 \mathrm{~cm}$ in depth. The Drükšiai- 6 aphanitic gray limestone contains impurities and lenticular greenish gray marl. At the bottom of the layer $(6 \mathrm{~cm})$, there is a limestone conglomerate. Pebbles in the conglomerate are oblong, with up to $5 \mathrm{~cm}$ long longaxis, and they are arranged horizontally. The ratio of limestone to marl is 9.5:0.5. This conglomerate overlies the interlayer of greenish marl.

It is impossible to trace the Drūkšiai Formation and distinguish Drūkšiai and Dysna formations on the southern part of the slope (Taučionis-49 and other sections), because of very thin and pyritisated rocks of the Oandu Stage.

The Dysna Formation of the Oandu Stage is distinguished in the Drūkšiai-6 drill-hole at the depth interval from 383.0 to $387.2 \mathrm{~m}$ and in the other sections of this area. It consists of gray pelitomorphic limestone with inclusions of the detritus of fauna. It is clearly layered and has dark spots of pyritisation. The limestone contains fuzzy interlayers and the inclusion of a greenish-gray and in the lower part gray-green layer of marl. Brachiopods, trilobites and bryozoans are abundant in the limestone. The depth interval from 385.0 to 385.3 and the depth of $387.2 \mathrm{~m}$ is marked by biomorphic interlayers of very pyritised limestone the thicknesses of which are $3.0,2.5,2.0 \mathrm{~cm}$, respectively. At the base of the layer $(8 \mathrm{~cm})$, there are interlayers of limestone conglomerate. Its 


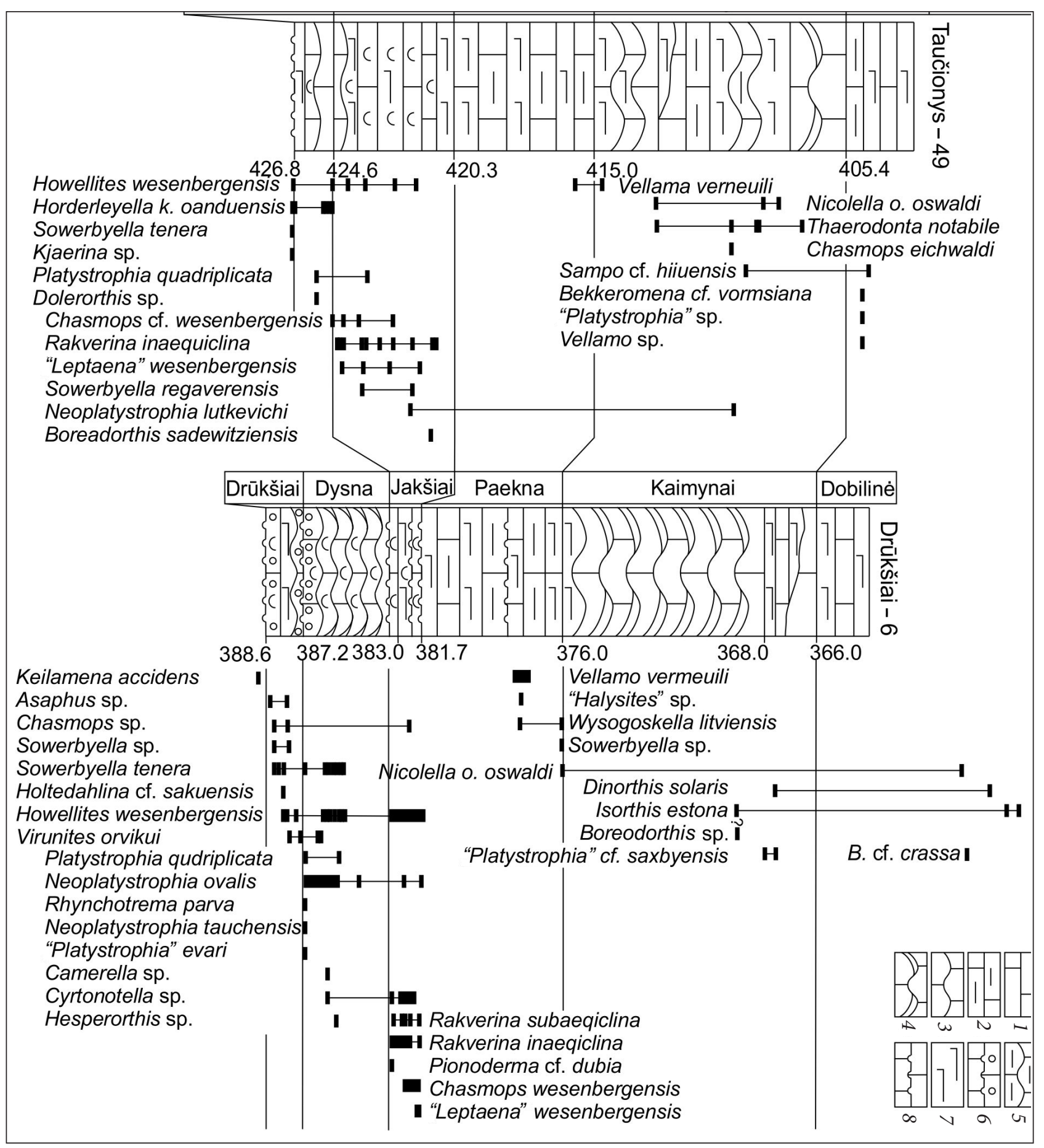

Fig. 2. Geological sections of the Taučionys-49 and Drūkšiai-6 drill-holes with a vertical distribution of the fauna. 1 - limestone, 2 - clayey limestone, 3 - nodular limestone, 4 - nodular limestone with marl intercalations, 5 - nodular clayey limestone - 6 - limestone with pyritised surface and basal carbonate conglomerate, 7 - marl, 8 - limestone with pyritised break surface

fragments are presented by the pelitomorphic gray limestone nodules, medium rounded with the size up to $4 \mathrm{~cm}$ in diameter, which compose about $55 \%$ of the rock. The surface of debris is covered by pyritised rim. The cement of the conglomerate is composed of gray and often coarse calcite. The ratio of limestone to marl is 8:2 in the lower part of the layer, and 9:1 at its top. This formation has not been distinguished in the Taučionis- 49 well section. 
The Jakšiai Formation of the Rakvere Stage is notable for low thickness in the Drūkšiai-6 core. It is distinguished at a depth range of $381.7-383.0 \mathrm{~m}$ in the borehole. This formation in the Taučionys- 49 drill-hole is distinguished at the depths of 420.3$424.6 \mathrm{~m}$, as well as in the drill-holes on the southeastern slope of the Middle Lithuanian Depression. The formation consists of limestone and marl interbeds. The limestone is gray, pyritised, sometimes clayey, and massive. The thickness of marl intercalations is $2-4 \mathrm{~cm}$. The marl is green, clayey, and massive; in some interlayers it contains abundant fauna of brachiopods and other fauna groups (biomorphic marl). The thickness of intercalations is $1-4 \mathrm{~cm}$; the maximum thickness is $21 \mathrm{~cm}$. The stratification is horizontal and wavy on the top. At the top of the layer, there is a pyritised surface. The ratio of limestone to marl is $4: 6$ in the lower part of the layer, and 9:1 at its top. The lower boundary of the layer is uneven with pyritised surface. The thin section of limestone from Taučionys- $49(421.5 \mathrm{~m})$ is characterised by organogenic-detrital texture. The organogenic debris accounts for $80 \%$ and clay material for $18 \%$ of the rock.

The Paekna Formation of the Nabala Regional Stage is distinguished in the Drūkšiai-6 drill-hole at the depth of $376.0-381.7 \mathrm{~m}$. This formation in other wells of Drūkšiai area, e. g. Taučionys-49, lies at the depth of $415-420.3 \mathrm{~m}$. It is also found in other well sections on the south-eastern slope of the Middle Lithuanian Depression. The thickness of the formation increases if compared to the underlying formations. The formation is characterised by the interbedded limestone and marl (1:1). The limestone in the Drūkšiai-6 core is gray, microcrystalline, and massive. The marl is gray, and massive. The thickness of limestone layers varies between $4-7 \mathrm{~cm}$, rarely up to $11 \mathrm{~cm}$; and that for marl is $3-6 \mathrm{~cm}$, occasionally $23 \mathrm{~cm}$. The lamination is horizontal. At the depth of $377.8 \mathrm{~m}$, there are traces of intense pyritisation marking sedimentation gap at the surface of the limestone. The lower boundary layer is uneven, marked by a double pyritised surface of the sedimentary break. The limestone in thin sections of the Taucionys-49 core at the sample depth of $416.4 \mathrm{~m}$ is characterised by the fine-grained texture, with a spotted structure. It consists of $80 \%$ of calcite grains, $14 \%$ of the clay material, $4 \%$ - of organogenous chips and $2 \%$ of ore minerals. Glauconite grains in the sections of the slope depression are not found.

The Kaimynai Formation of the Nabala Regional Stage in the Drūkšiai-6 well core lies at the depth of 368.0-376.0 $\mathrm{m}$ and in the other sections of this area, e. g. Taučionys- 49 , at the depth of $405.4-415.0 \mathrm{~m}$. It is also found in the core sections on the south-eastern slope of the Middle Lithuanian Depression. The formation in the Drūkšiai-6 drillhole consists of interbedded limestones and marl, with their ratio being 7:3. The limestone is gray, sometimes spotty because of pyritisation, massive, and contains an admixture of pyritised detritus of various sizes, as well as rare brachiopods. The grey marl, in some parts clayey, contains organogenic detritus, massive. The fauna in the limestone has cavities $(1.5 \mathrm{~cm})$ incrusted by calcite. The thickness of the limestone interlayers is from 7 to $11 \mathrm{~cm}$, rarely $3-7 \mathrm{~cm}$. The marl beds in the formation are from 2 to $4 \mathrm{~cm}$ thick, rarely up to $10 \mathrm{~cm}$; well horizontally stratified with wavy-banded intervals. The lower part is distinguished by the appearance of a thicker marl interlayer. The marl in the Taučionis-49 drill-hole at the depth of $411.5 \mathrm{~m}$ is composed of $\mathrm{CaO}(24.53 \%), \mathrm{MgO}(0.43 \%)$, and insoluble residue (50.50\%).

The top layer of the Kaimynai Formation is presented in the Drūkšiai- 6 drill-hole at the depth of 366.0-368 $\mathrm{m}$ by gray limestone with an admixture of black microcrystalline pyritised detritus (15\%), massive, containing interlayer of greenishgray marl. The thickness of limestone interlayers is within the range of $6-10 \mathrm{~cm}$, and those of marl are $1-2.5 \mathrm{~cm}$ thick. The lamination is wavy and banded to wavy. Limestone and marl ratio is 8.5:1.5. The lower limit is performed by the appearance of interlayer marl with horizontal stratification.

\section{BIOSTRATIGRAPHY AND CORRELATION OF THE STRATONS}

The biostratigraphy of the studied sediments is based on investigations of brachiopods, trilobites (Paškevičius, 1962; 1992¹) and ostracodes (Sidaravičienè, 1996).

\footnotetext{
1 The lists of fauna determined by Paškevičius $(1962,1992)$ in the boreholes of Taučionys-49, F 284-51; Drūkšiai-6, F284-109 and others specified by numerals are stored in the Manuscript Division of the Vilnius University Library.
} 
The deposits of the Katian Stage referred slope transgressively lie on an uneven surface of depositional break of the Viluciai Formation of the Keila Regional Stage. The age is indicated by such brachiopods as Horderleyella k. kegelensis (Alich.), Keilamena accidens (Orasp.) and others.

The correlation of beds of the Oandu-Nabala time is based on brachiopods, trilobites, ostracodes and graptolites, as well as on lithology and their stratigraphic position and occurrence (Fig. 3).

In order to correlate the beds studied, it is important to know the age of the Vilučiai Formation. According to the fauna of brachiopods and other groups, the beds belong to the Keila Regional Stage. The upper part of this formation in the zone of Livonian facies corresponds to the Blidene Member. This member is found to contain the following fauna: graptolites Diplograptus aff. irregularis Hadd., Climacograptus cf. rotundatus Jaan.-Skokl; and in the Adze Formation - Climacograptus cf. kukerrsianus Bulm., C. ex gr. skagensis Jaan.-Skokl., and Amplexograptus cf. falax Bulm. (Ulst et al., 1982; Paškevičius, 2011). Accordingly, Blidene Member could be correlated to the graptolite zone multidens and could be assigned to the Sandbian Stage (Hints, Paškevičius, Martma et al., 2016, in press).

The beds of the Katian Stage start from the above-described Drūkšiai Formation, and they were deposited on unevenly pyritised surfaces with the presence of basal conglomerate. The formation contains a new set of abundant brachiopods, especially based on the numbers of individuals of species Howellites wesenbergensis (Alich.), Horderleyel- la k. oanduensis Orasp., Sowerbyella tenera Rõõm, and Holtedahlina cf. sakuensis Orasp, Virunites orvikui (Orasp.) and other types of the Oandu Stage (Laškov, Marcinkevičius, Paškevičius, 1993) (Fig. 2). The correlation of the Drūkšiai Formation with the deposits of the Oandu Stage is supported by the remains of ostracodes from Klimphores minimus zone. It overlies beds of Drūkšiai, Dysna and Jakšiai formations of the Oandu-Rakvere time. In the subzone of the Drūkšiai Formation Ardennea? nearda (Sidaravičiene, 1996) is distinguished.

The beds of the Dysna Formation in the drillholes of Drūkšiai area lie transgressively (with developed limestone conglomerates at its base). The limestones and marls of the formation are biomorphic. They contain Neoplatystrophia ovalis (Alich.), N. tauchensis (Pašk. et Dag. in litt.), Platystrophia quadriplicata Alich., P. evari Orasp., and Rhynchotreta parva Orasp., whereas Howellites wesenbergensis (Alich.), Sowerbyella tenera Rõõm., Virunites orvikui (Orasp.) and others come here from the Drūkšiai Formation. At this stratigraphic level of Sutkai-89 and Pajevonis-13, as well as Kybartai-29 drill-holes, the author and L. Hints found and paleontologically described a new species of Dolerorthis nadruvensis Pašk. et Hints (Paškevičius, Hints, 2016, in press).

The Drūkšiai and Dysna Formations could be compared by the brachiopod community Platystrophia quadriplicata-Neoplatystrophia ovalis (Paškevičius, 2000).

A subzone of ostracodes Pelecybolbina i. bisulcata-Sigmoopsis granulata within the zone of

\begin{tabular}{|c|c|c|c|c|c|c|}
\hline \multirow{3}{*}{$\frac{d}{\frac{\pi}{\pi}}$} & \multirow{3}{*}{$\begin{array}{l}\text { Graptolite } \\
\text { zones }\end{array}$} & \multirow{3}{*}{$\begin{array}{l}\text { Regional Stage } \\
\text { of the Baltic } \\
\text { Basin }\end{array}$} & \multirow{2}{*}{\multicolumn{2}{|c|}{$\begin{array}{l}\text { Livonian facies belt } \\
\text { Jelgava Depression }\end{array}$}} & \multicolumn{2}{|c|}{$\begin{array}{l}\text { Lithuania facies belt } \\
\text { Middle Lithuania Depression }\end{array}$} \\
\hline & & & & & Central part & Southeastern slope \\
\hline & & & \multicolumn{2}{|c|}{ Formation, Member } & \multicolumn{2}{|c|}{ Formation } \\
\hline \multirow{6}{*}{ 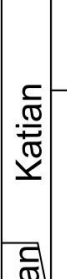 } & \multirow{2}{*}{ linearis } & Vormsi & \multicolumn{2}{|c|}{ Fäcka } & \multicolumn{2}{|c|}{ Dobilynè } \\
\hline & & \multirow{2}{*}{ Nabala } & \multicolumn{2}{|c|}{ Saunja } & \multicolumn{2}{|c|}{ Kaimynai } \\
\hline & \multirow{4}{*}{ clingani } & & \multicolumn{2}{|c|}{ Paekna } & \multicolumn{2}{|c|}{ Paekna } \\
\hline & & Rakvere & \multicolumn{2}{|c|}{ Keklys } & \multicolumn{2}{|c|}{ Jakšiai } \\
\hline & & \multirow{2}{*}{ Oandu } & \multirow{2}{*}{ Mossen } & Žarènai & Šakiai & Dysna \\
\hline & & & & Plungè & Alvitas & Drūkšiai \\
\hline \multirow{2}{*}{$\begin{array}{l}\frac{0}{0} \\
\text { 焉 } \\
\text { ஸी }\end{array}$} & \multirow{2}{*}{ multidens } & \multirow{2}{*}{ Keila } & \multirow{2}{*}{\multicolumn{2}{|c|}{ Adze }} & \multicolumn{2}{|c|}{ Vilučiai } \\
\hline & & & & & \multicolumn{2}{|c|}{ Auleliai } \\
\hline
\end{tabular}

Fig. 3. Correlation of the stratigraphic units of the Katian Stage in the Middle Lithuanian Depression of the Lithuanian facies zone and the Jelgava Depression of the Livonian facies zone 
Klimphores minimus is distinguished in the Dysna Formation for the Oandu Stage. It suggests that the beds of Drūkšiai and Dysna Formations contain the fauna of brachiopods, ostracods of the Oandus time and also have a distinctive lithostratigraphic sediment composition. Thus, both formation deposits are comparable with the Oandu Stage of the Baltic Basin.

The beds of the Drükšiai Formation of the Oandu Regional Stage are comparable to the deposits of the Alvitas Formation in the axial part of the Middle Lithuanian Depression, where these rocks contain the following fauna of brachiopods: Neoplatystrophia ovalis (Alich.), Platystrophia quadriplicata Alich., Howellites wesenbergensis (Alich.), and Onnella longa Hints, Sowerbyella tenera Rõõm et al. (Fig. 2). The layers of bluish-gray marls and calcareous clayey marls within biomorphic limestone of the Drūkšiai Formation can be coeval of marls and clays of the Alvitas Formation. These beds are situated between the two formations of Vilučiai and Dysna, and Vilučiai and Šakiai, i. e. they are at the same stratigraphic level.

The correlation of Dysna and Šakiai formations is confirmed by the same faunal complex of brachiopods. However, the lithology of the formations is quite different. The Dysna Formation is dominated by the biomorphic limestones with marl percolations, while the Šakiai Formation contains well-developed greenish-gray marl with biomorphic limestones. Nevertheless, their stratigraphic position should be identical.

The comparison of Drūkšiai and Dysna formations to the Plungè and Žarènai members of the Mossen Formation from the Livonian facies zone is complicated because of the different facies. The Plunge Member is represented by the black mudstones with graptolite fauna of the $\mathrm{Di}$ cranograptus clingani zone (Paškevičius 1973, 2011). Inclusions of black argillite in marls of the Alvitas Formation (Virbalis-5 ) provide a basis to attribute it to the Plunge Member of the Alvitas Formation and to the Drūkšiai Formation.

Upwards, the overlying Žarenai Member of the Mossen Formation in the Livonian facies zone consists of greenish-gray marls with thin interbedded marly limestones with fossils of trilobites Flexicalymene jamtlandica Thorsl. and thin-walled brachiopods. This trilobite has been for the first time recognised in the upper Chasmops layers around
Stengärde, Jemtlande Sweden in the layers of clingani zone (Thorslund, 1940). On the basis of stratigraphic position and recognized fauna of trilobites, the Žarenai Formation should be paralleled with the Šakiai and Dysna formations of the Middle Lithuanian Depression and the clingani graptolite zone.

The Jakšiai Formation also includes a full range of brachiopods. For the first time, the brachiopods Neoplatystrophia l. lutkevichi (Alich.), Boreadorthis sadewitziensis (Roem.), Hedstroemina inequiclina (Alich.), H. subaequiclina (Alich.), Leptaena wesenbergensis Alich., and Pionodema cf. dubia Hints; as well as trilobites Chasmops wesenbergensis Schm. appear in this formation. A transition of Howellites wesenbergensis (Alich.), Platystrophia qudriplicata Alich., Neoplatystrophia ovalis (Alich.), Cyrtonotella sp. and etc. from the Dysna Formation of the Oandu time into the Jakšiai Formation is also observed

The brachiopod community of Boreadorthis sadewitziensis-Hedstroemina inaequiclina distinguished by the author (Paškevičius, 2000) is widespread in the beds of the Jakšiai Formation.

Using the ostracodes in the Jakšiai Formation, a subzone of Pelecybolbina composita-Daleiella admiranda of the Rakvere Stage has been distinguished from the zone of Klimphores minimus.

Based upon the indicated fauna of brachiopods, their communities, trilobites and ostracode subzones and lithostratigraphy of beds, the Jakšiai Formation undoubtedly should be compared with the Rakvere Stage of the Baltic Basin.

Deposits of the Jakšiai Formation of the Rakvere age overlie Dysna and Šakiai formations in the axial part of the Middle Lithuanian Depression and on its slope. The following brachiopods are recognised in the deposits of the Jakšiai Formation: Howellites wesenbergensis, Hedstroemina inaequiclina, and $H$. subaequiclina etc.; as well as trilobites Chasmops wesenbergensis. Additionally, the presence of nodular aphanitic limestones and their stratigraphic position gives the opportunity to correlate deposits of the formation with the Keklis Formation and the clingani graptolite zone of the Livonian facies zone (Paškevičius, 2011).

The beds of the Paekna Formation overlie the uneven pyritised surface of sedimentary break. One more pyritised surface is also distinguished in the middle of the formation. Formation deposits are less rich with respect to fauna of brachiopods 
and other groups. In the sections of Drūkšiai-6 and Taučionis-49, Vellamo verneuili (Eichw.), Wysogorskella litwiensis Hints, "Halysites" sp. have been found. In other sections, Neoplatystrophia lutkevichi satura (Orasp), Pseudolingula quadrata (Eichw.), Laticrura rostrata Hints, Dalmanella aluverensis Hints, etc. were found.

The brachiopod community of Wysogorskella litviensis-Neoplatystrophia lutkevichi satura is coeval with the Paekna Formation.

Sidaravičiene (1996) distinguished an interzone of ostracodes in the Paekna Formation.

On the basis of the fauna described, the Paekna Formation should be compared with the Nabala Stage of the Baltic Basin.

The beds of the Paekna Formation of the Lower Nabala age could be distinguished in the Middle Lithuanian Depression as well as Jelgava depressions. Their synchrony is confirmed by the presence of similar scarce fauna of brachiopods, graptolites Climacograptus diplacanthus Bulm., Lassiograptus cf. harknessi (Nich.), etc. (Männil, 1976), as well as interbedded clayey limestones with rough clay marls, which gives grounds to match the Paekna Formation with the clingani zone (Paškevičius, 1973).

The Kaimynai Formation is represented by thicker deposits of interbedding of nodular limestone and marl. They are not as rich in brachiopods, of which the following ones should be mentioned in the Drūkšiai-6 and Taučionys-49 drill-holes: "Platystrophia", cf. saxbyensis Orasp., Boreadorthis sp., Nicolella o. oswaldi (Buch), Therodonta notabile Pašk. sp. nov. (palaeontological description presented in this article), and Vellamo verneuili (Eichw.), as well as trilobite Chasmops eichwaldi Schm. Other sections of this formation have been found to contain Isorthis sp., Imarinia sinuata (Pahlen), Cyclospira? levisulcata Rõõm., and Triplesia insularis (Eichw.).

The author has identified brachiopod community "Platystrophia" saxbyensis-Ilmarinia sinuata that is observed in the beds of the Kaimynai Formation.

Based on the study of ostracodes, Sidaravičiene (1996) attributed the Paekna, Kaimynai and Dobilyne formations in the sections of Drūkšiai area to the Vormsi Stage. However, this should be denied by fauna of brachiopods and trilobites indicated by us, as well as by the stratigraphic position of the formations, the presence of nodular lime- stone as the age analogues of Paekna and Saunja formations in Estonia. Moreover, the Vormsi rocks are notable for a horizontal deposition of limestone and marl around the Middle Lithuanian Depression, as is observed in the overlying Dobilyne Formation. It should be stressed also that there is no analogous stratigraphic volume and thickness of deposits of the Vormsi Stage in the Middle Lithuanian Depression. Finally, the zone of ostracodes of the Vormsi Stage, its index species Tetradella intricata and Klimphores holdrensis are lying mainly above the Dobilyne Formation.

Taking into account the indications on the fauna of brachiopods and trilobites, stratigraphic position of the ostracode zones of Tetradella intricata and Klimphores holdrensis, as well as lithological features of these rocks and their occurrence conditions, the Kaimynai Formation should be compared to the Nabala Stage of the Baltic Basin.

The beds of the Kaimynai Formation of the Upper Nabala age are developed in the Middle Lithuanian and Jelgava Depressions. This formation in the Middle Lithuanian Depression is younger, as is concluded from the composition of the fauna of brachiopods, trilobites and graptolites, nodular wavy interbedding of limestone with marl, overlain by the rocks of the Dobilyne Formation with fauna of the Vormsi age. The Kaimynai Formation in the Livonian facies zone is comparable in age with the Saunja Formation in Estonia. The formation is found to contain the following graptolites: Orthograptus cf. gracilis (Roem.), Dicellograptus sp., and Archiretiolites regimontanus Eis. (Paškevičius, 1973; Männil, 1976), indicating their correlation with the linearis zone.

Let us return to the stratigraphy of the Oandu Regional Stage. The volume of this stage in the stratotypic locality of Estonia is not complete. In its geological section, there is a significant stratigraphic gap between the formations of Vasalema and Hirmuse, representing the lower part of the Oandu Stage (Hints, Paškevičius et al., 2016, in press). The indicated gap can be compensated by the marls and limestones of the Oandu Stage in Lithuania in the form of Alvitas and Šakiai formations in the axial part of the Middle Lithuanian Depression. The thickness of these formations ranges from $10 \mathrm{~m}$ (Pajevonys-13) up to $16 \mathrm{~m}$ (Krekenava-7) with numerous well-preserved and characteristic fauna of brachiopods, bryozoa, trilobites, 
ostracodes, chitinozoans, conodonts, graptolites, and other groups. For the Lithuanian complete section, the characteristic species of brachiopods are as follows: Dolerorthis nadruvensis Pašk. et Hints, Reuschella magna Hints, Howellites wesenbergensis (Alich.), Skenidioides sp., Sampo suduvensis Pašk, et Hints, Hedstroemina inaequiclina (Alich.), Parastrophina dura (Orasp.), etc., with their stratotypical areas absent or less developed. The mentioned specified stratotype area is notable for a particularly prevalent group of leptaenas: Similoleptaena ingrida Rõõm., "Leptaena" sp. and others. Kjaerina poljensis (Alich.), Chasmops extensus (Boeck), etc. are also prevalent. The described fauna in the axial part of the Middle Lithuanian Depression is also known in the upper part of the Šakiai Formation. Thus, this fauna confirms the presence of the continuous complete Oandu Stage in the Middle Lithuanian Depression and incompleteness of this stage in the stratotype section.

The indicated fauna (Reuschella, Skenidioides, Hedstroemina, Parastrophina) of Lithuania originated or had relations with the fauna of the Laurentia and Avalonia regions (Hints, Paškevičius et al., 2016, in press).

Thus, the section of the borehole Pajevonys-13 from Lithuania could serve as an important parastratotype complementing stratigraphy of the Oandu Stage in the Baltic Ordovician Basin.

Palaeontological description of Thaerodonta notabile sp. nov.

\section{Genus Thaerodonta Wang, 1949}

Genotype. Thaerodonta aspera Wang, 1949 from the USA, north-eastern part of Iowa, Mississippi Valley, Maquoketa shale, Upper Ordovician

Thaerodonta notabile ${ }^{2}$ Paškevičius sp. nov.

Plate, Figs. $\mathrm{A}_{1}-\mathrm{E}_{3}$

Holotype. Thaerodonta notabile Pašk. sp. nov., No. 85, ventral and dorsal valves (Plate, Figs. $\mathrm{A}_{1}$ and $\mathrm{A}_{2}$ ) from the Taučionys-49 well, depth 406.9 m, Kaimynai Formation, Nabala Regional Stage, Katian, Upper Ordovician.

Material. 12 complete and crushed valves from 5 Lithuanian deep wells.

Description. Shells are oval or of irregular trapezoid shape, medium size, oblong, external line is semicircular, lateral profile is concavo-convex, maximum width is in the middle of the shell closer to the interarea. Ventral valve over the middle part is more concave, dorsal valves ventrally bent. Inter- locking angle with the edge of the ventral valve is obtuse (about $65^{\circ}$ ), and the dorsal one is closer to the right angle. Lobus edge is rounded. Delthyrium is close in shape to the isosceles triangle. Its umbonal part is wide (for size measurements see Table).

On the ventral surface of the valve at the front edge, there are 30 and sometimes more basic costellae (rays), and 7-10 smaller rays occur among them after bifurcations additionally. Under the top raylike layer of a valve, there are oblong pseudo-speckles covering valves in radial rows observed. No valve with the internal structure of this type valve has been found.

Ventral area of the valve is narrow, it is especially narrowing towards the side of the shell, straight, slightly curved towards delthyrium, its maximum height is $2.25 \mathrm{~mm}$. Base width of the delthyrium is $3 \mathrm{~mm}$. At the edges of the narrow delthyrium, there are deltidial plates developed.

Structures of the dorsal valve are noticeable. Its interarea is shorter and hyperclinical. The edge of the valve in its inner part has denticles, on the one side of the valve there are more than 15 rounded denticles, the maximum abundance of denticles is closer to the back (due to diagenesis and epigenesis, they become hardly detectable), cardinal denticles are small. Cardinal process is well developed, powerful, and triangular in shape, the primary middle lobe extends into the interior of the shell. Chilidial plates are powerful, separated from the process by the visible furrows. The described plates merge with 1.7-mm-long brahiophores, they are obtuse, after expanding by dividing, they border the notothyrium, which is thickened, with a bloated shell that is deep, oval, $2 \mathrm{~mm}$ long and $3 \mathrm{~mm}$ wide. Branches of brahiophores are thinner in the front and grow closer to one another. To the ends of the specified ramifications of brahiophores, two adjacent raised central septa attach, which in the front of the valve thicken and rise. Among the described septae, there are small channels $9.5 \mathrm{~mm}$ long and $2 \mathrm{~mm}$ wide. The ends of the septae towards the front edge are quite papillose. Side-on from these septae, there are less developed lateral septae, and behind them there is an unclearly developed muscular field up to $10 \mathrm{~mm}$ long and $3.5 \mathrm{~mm}$ wide, and the lateral scar central adductors are not clearly expressed. There are wide vein strips. The front of the dorsal valve is covered by the strips of micro-papilae, which converge to the back and subsequently thicken. 
Table. The measurements of the Thaerodonta notabile sp. nov. ( $\mathrm{mm}$ )

\begin{tabular}{|c|c|c|c|c|c|c|c|c|}
\hline Location, Age & Shell shape & $\begin{array}{l}\text { Table, } \\
\text { Figure }\end{array}$ & No. & Lenght & Width & $\begin{array}{l}\text { Width to } \\
\text { lenght ratio }\end{array}$ & $\begin{array}{l}\text { Con- } \\
\text { cavity }\end{array}$ & $\begin{array}{l}\text { Major } \\
\text { ribs }\end{array}$ \\
\hline \multirow{5}{*}{ Taučionys-49, Nabala } & Shell oval Holotype & $\mathrm{A}_{1}-\mathrm{A}_{5}$ & B85 & 15 & 20 & 0.75 & 6 & 30 \\
\hline & Improper trapez. Dorsal & $\mathrm{E}_{1}-\mathrm{E}_{3}$ & B87 & 9.7 & 19.5 & 0.5 & 6 & \\
\hline & & $\mathrm{B}$ & B88 & 12 & 15 & & 6 & 30 \\
\hline & Improper trapez Ventral & $\mathrm{D}_{1}-\mathrm{D}_{2}$ & B90 & 14 & 20 & 0.7 & & \\
\hline & Improper trapez. Dorsal & & B91 & 15 & 26 & 0.75 & & \\
\hline \multirow{2}{*}{ K. Vokè-1, Nabala } & Oval Dorsal & $\mathrm{C}$ & B82 & 12 & 18 & 0.7 & 6 & \\
\hline & Oval Ventral & & B81 & 12.4 & 20.1 & 0.6 & 6 & 32 \\
\hline Prienai-3 & Oval Ventral & & $\mathrm{B} 80$ & 10 & 18.4 & 0.54 & 7 & 34 \\
\hline Paukščiai-192, Nabala & Improper trapez. Dorsal & & B83 & 10.2 & 18.4 & 0.55 & 6 & 30 \\
\hline Drūkšiai-6, Vormsi & Oval Ventral & & B86 & 12 & 15 & 0.8 & 6 & \\
\hline
\end{tabular}

2 notabile (lat.) - notable.

Comparison. Genus Thaerodonta - based on its size, outline, dorsal lateral septa, radial ornamentation of valve costellae surfaces, which divide surface into segments - is closely related to the genus Eoplectodonta. There are also significant differences between these two genera. Eoplectodonta in the dorsal valve have additional fossettes and corresponding denticles occur only in the pedicle. On the other hand, denticulation of Thaerodonta always has oppositions (contrast Figs. 1 and 4 with Figs. 5 and 9 in the 2nd plate; Howe, 1972). In the genus Thaerodonta, there is no distinct well-defined dorsal medial septa and extremal oblique wrinkling, as for example in the genus Eoplectodonta. Cooper (1956) showed that the genus Eoplectodonta does not have frontal branching of the medial septa in the ventral valve, which is typical of Sowerbyella, and also it is a diagnostic of the genus Thaerodonta (Cocks, 2013; Howe, 1972).

The described species Thaerodonta notabile sp. nov. should be compared with Thaerodonta aspera Wang, 1949, Table 11, Figs. C 1-5, p. 20 of Maquoketa shale, Elgin limestone of Upper Ordovician, Iowa, USA. The described Lithuanian species differs from the American species in size of the valve, and its shape in larger curvature. The thickness of the valve of the Lithuanian species is $5-7 \mathrm{~mm}$ compared to 3-5 $\mathrm{mm}$ of the American one. Surface sculpture of shells: in the Lithuanian species there are more basic costae (rays), they are not identical in size and unevenly distributed. There are differences in the inner structure of the dorsal valve, es- pecially in the shape of the cardinal process, back denticles, hilidium plates and brachial processes.

The new Lithuanian species should be compared with the American species Thaerodonta saxea (Sardeson) in 1892 from the same place of the United States (Wang, 1949, Table 11, Figs. 1-5, p. 21). The sculpture of the surface of shells, their costae, size and shape of both species are close, but the internal structure of the dorsal leaf is different, especially in the back appendage cardinal process and the brachial process.

Thaerodonta recedens (Sardeson) occurs in the USA in the same place as Th. saxea (Sardeson) (Howe, 1972, Plate 3, Fig. 7). There are differences in the inner structure of the dorsal valve. Th. recedens differs from the described Lithuanian species by having well-developed additional denticles.

Thaerodonta magna Howe from the USA, Richmond outcrop (Montoya Group), Hueco Mountains, Texas. This species differs from Th. notabile having pedicle interior showing large accessory teeth, delthyrium thickening, and deeply incised pits for attachment of adductors (Howe, 1972, Plate 1, Fig. 11).

Thaerodonta carksvillensis (Forste) from the USA, Richmond outcrop, which is near Oxford, Ohio (Howe, 1972, Plate 1, Figs. 1-3). It differs from the Lithuanian species in its outline, inner structure of a dorsal valve, more pronounced lateral margins of muscular fields, and also larger bulging of this margin. Two brachial interiors showing variation in lateral septa. 


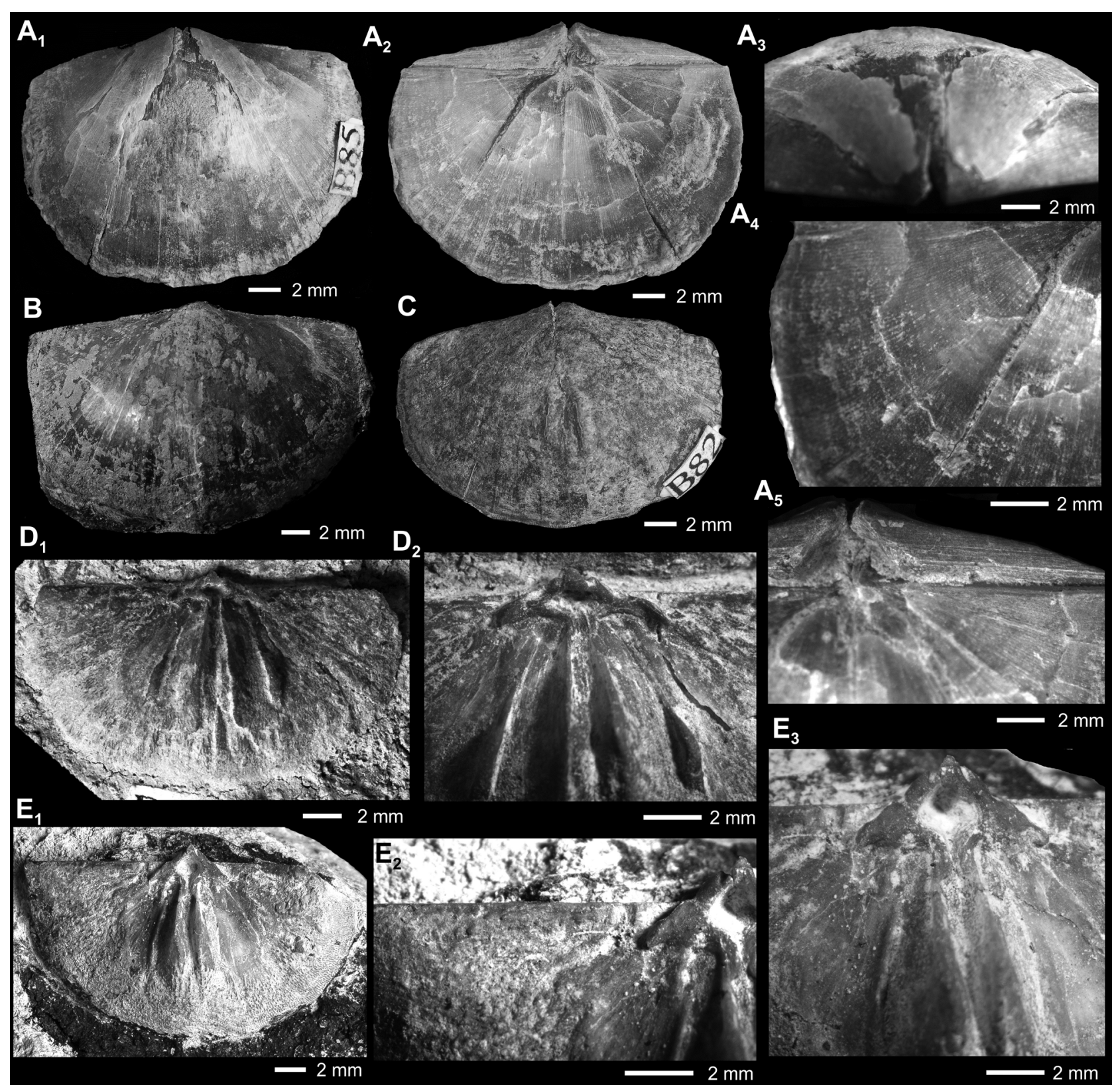

Plate. Thaerodonta notabile sp. nov.

A - VU B85, shell; $A_{1}$ - ventral valve, expanded convexity at the umbonal part; $A_{2}$ - dorsal valve with an areas and delthyrium; $A_{3}$ - valve arch; $A_{4}$ - dorsal shells sculpture with the first and second series of ridges costellae (rays); $A_{5}$ - areas and damaged lock mechanism. Holotype. Taučionys-49, a borehole depth of 406.9 m. Kaimynai FM, Nabala Stage.

B - VU B88, ventral valve, observed the surface of the sculpture. Taučionys-49, depth $412.3 \mathrm{~m}$, Kaimynai FM, Nabala Stage.

C - VU B82, ventral valve affected by the diagenesis and epigenesis. Because of this, surface sculpture is invisible. Kauno Vokè-1 well, depth 283.0 m. Paekna and Kaimynai FMs are not distinguished, Nabala Stage.

$\mathrm{D}_{1}$ - VU B90, dorsal valves inner structure; $\mathrm{D}_{2}$ - magnified locks mechanism: cardinal process, notothyrium, brachiophore etc. Taučionys- 49 drill-hole, depth 412.3 m. Kaimynai FM, Nabala Stage.

$\mathrm{E}_{1}$ - VU B87. dorsal valves inner structure; $\mathrm{E}_{2}$ - edge of the dorsal shells locks with noticeably small rounded denticles; $\mathrm{E}_{3}$ - magnified locks mechanism: cardinal process, notothyrium, brachiophores etc. Taučionys-49 drill-hole, depth 409.8 m. Kaimynai FM, Nabala Stage. 
Association. This species is found alongside with the brachiopods "Platystrophia" sp., Boreadorthis sp., Nicolella oswaldi oswaldi (Buch), Isorthis sp., Leptaena sp., Sowerbyella sp., trilobites Chasmops eichwaldi Schm., and also Rugosa, Bryozoa, Crinoidea, etc.

Distribution and age. For the first time in the Lithuanian facies zone, the genus Thaerodonta and its new species have been found in the clayey limestones of the Kaimynai Formation of the Nabala Regional Stage and Katian Stage. Rare finds of this species are detected in the deposits of Vormsi. Thaerodonta notabile has been detected in limestone of many deep drill-holes of the Middle Lithuanian Depression.

Locations. The described species Thaerodonta notabile has been found in a number of core sections in the Middle Lithuanian Depression of the Lithuanian facies zone: Taučionys -49 , depth $406.9 \mathrm{~m}$ (No. B85, holotype), depth $409.55 \mathrm{~m}$ (No. B89, B89a), depth $409.8 \mathrm{~m}$ (B87), depth $412.3 \mathrm{~m}$ (B88), depth $412.5 \mathrm{~m}$ (B90, (B91)); Kauno Vokè-1, depth $283.0 \mathrm{~m}$ (B80, B81, B82); Prienai-3, depth 652-658 m (B80); Paukščiai-192, depth 506-512 m (B83); Drūkšiai-6 (Kazimirovo), depth $357.15 \mathrm{~m}$ (No. B90?). The collection is stored in the Geological Museum of the Department of Geology and Mineralogy at the Vilnius University, VU, No. coll. 15.

Received 5 February 2016 Accepted 26 April 2016

\section{References}

1. Cocks L., Robin M. 2013. Generic identities and relationships within the Brachiopod Family Sowerbyellidae. Palaeontology. 56(1): 167-181.

2. Hints L., Paškevičius J., Martma T., Mänik P. Nõlvak J. 2016. Upper Sandbian - Lower Katian bio- and chemostratigraphy in the Paevonys-13 core section, Lithuania (in press).

3. Howe Herbert J. 1972. Morphology of the Brachiopod genus Thaerodonta. Journal of Paleontology. 46(3): 440-446.

4. Musteikis P., Paškevičius J. 1999. Brachiopod communities of the Lithuanian Silurian. In: A. J. Boucot and J. D. Lawson (eds.). Paleocommunites - a case study from the Silurian and Lower Devonian. World and Regional Geology. II. Cambridge University Press. 305-326.

5. Lashkov J. M., Pashkevichius J. J. 1991. Strukturnofacial'noe rayonirovanie i litostratigrafiya ordovika
Jugo-Vostochnoy Pribaltiki. Nauch. tr. vuzov Litvy. Geologija. 12: 9-20 [in Russian].

6. Lashkov J. M., Marcinkevichius V. I., Pashkevichius J. J. 1993. Stratigrafiya i stroeniya karbonatnykh otlozhehii ordovika jyugo-vostochnoy chiasti Baltiyskogo basseina (Drukshaiyskaya ploshchiad'). Nauch. tr. vuzov Litvy. Geologija. 14(I); 81-98 [in Russian].

7. Männil R. M. 1976. Raspredelene graptoloidey v karbonatnych otlozheniyach ordovika Pribaltiki. Graptolity $i$ stratigrafiya. Red. D. L. Kalyo, T. N. Koren'. Tallinn. 105-118 [in Russian].

8. Pashkevichius J. 1958. Stratigrafiya i fauna ordovikskich-siluriyskich otlozhenii Juzhnoy Pribaltiki. Autoref. dis. na soiskanie uch. stepeni kand. geol.-miner. n. Vilniusskii universitet. 23 s. [in Russian].

9. Pashkevichius J. 1973. Biostratigrafiya, koreliaciya $i$ graptolity ordovikskich $i$ siluriskich otlozhenii Juzhnoy Pribaltiki. Autoref. dis. na soiskanie uch. stepeni dr. geol.-miner. n. Vilniusskii universitet. 67 s. [in Russian].

10. Paškevičius J. 2000. Baltijos oroviko baseino, Lietuvos facijų zonos brachiopodų bendrijos (plati santrauka anglų k.). Geologija. 32: 14-35 (with extended English abstract).

11. Paškevičius J. 2004. Ordoviko brachiopodai. Žemès gelmiu raida ir ištekliai. Vilnius. 153-166 [in Lithuanian].

12. Paškevičius J. 2011. The Ordovician and Graptolites of Lithuania. Saarbrücken: LAP LAMBERT Academic Publishing. $107 \mathrm{p}$.

13. Paškevičius J., Hints L. 2016. New Plectambonitid and Hesperortid brachiopods from early Katian in Lithuania (in press).

14. Sidaravichiene N. 1992. Ostrakody ordovika Litvy. Vilnius. 252 s. [in Russian].

15. Sidaravičienė N. 1996. Lietuvos ordoviko ostrakodai, biostratigrafija. Vilnius. 81 p. [in Lithuanian].

16. Thorslund Per. 1940. On the chasmops series of Jemtland and Södermanland (Tvären). Sveriges Geologiska Undersöking, Ser C, No. 436. Stockholm. Årsbok 34(6): 147-148, Table 12, Fig. 19-22.

17. Ulst R. Zh., Gailite L. K., Jakovleva V. I. 1982. Ordovik Latvii. Riga: Zinatne. 137-139 [in Russian].

18. Wang Y. 1949. Maquoketa Brachiopoda of Iowa. The Geological Society of America. Memoir 42: 1922; Paleontological Plate 11.

Archive references

1. Vaitonis V., Šliaupa A., Čibiraitè A., Vienožinskis V. 1962. Otchiot o kompleksnoy geologo-gidrogeologicheskoy s'mke mashtaba 1:200 000 na teritorii lista N-35-XIII (Daugaiyskoy kompleksnoy geologo-s'mochnyy otryad 1961-1962 g. T. II. Knyga 1. Tekstovaya prilozheniya. Vilnius. 56-57 [in Russian].

2. Marcinkevichius V. 1995. Otchiot o provedennoy geologo-gidrogeologicheskoy i inzhinerno- 
geologicheskoy s'emke m-ba 1:50 $0000 \mathrm{v}$ rayone Ignalinskoy AEC na territorii listov N-35-17-5; N-35-18-A; N-35-17-Г, a, 6; N-35-18-B, a, 6 v predelach Litovskoy Respubliki i Respublik Belarus' do izucheniem geologo-gidrogeologicheskich uslovii v predelach Litovskoy Respubliki (Drukshiayskii ob’ekt). T. 1. Knyga 2. Tekstovaye prilozheniya. Opisaniya kerna strukturnych ckvazhin. Vilnius. 310-316 [in Russian].

\section{Juozas Paškevičius}

\section{LIETUVOS FACIJŲ ZONOS ANKSTYVOJO KAČIO (ORDOVIKAS) LITOLOGIJOS IR FAUNOS YPATUMAI}

Santrauka

Remiantis Lietuvos facijų zonos, Vidurio Lietuvos ịlinkio pietrytinio šlaito Taučionių-49, Drūkšių-6 ir kitais gręžiniais, jų kernų aprašymu, paimtais paleontologiniams tyrimams pavyzdžiais, brachiopodų ir kitų faunos grupių apibūdinimais bei ostrakodų tyrimu, buvo atliktas gręžinių pjūvių stratigrafinis suskirstymas.
Analizuota minèto šlaito Drūkšių, Dysnos, Jakšių, Paeknos ir Kaimynų svitų, skiriamų Oandų-Nabalos regioniniams aukštams, litostratigrafija. Brachiopodų, trilobitų ir ostrakodų faunos tyrimai leido pagrịsti minètų svitų biostratigrafiją. Esant Estijos stratotipiniame pjūvyje, Oandu regiono aukšte stratigrafinei pertraukai, ją papildo nepertraukiamas Lietuvos Pajevonio-13 gręžinio parastratotipinis pjūvis. Pažymèta, kad N. Sidaravičienès (1996) Drūkšių ploto gręžiniuose Paeknos, Kaimynų ir Dobilynès svitų priskyrimas Vormsio aukštui yra taisytinas, reikètų palikti jame tik Dobilynès svitą. Pateikta minètų svitų koreliacija su Vidurio Lietuvos ịlinkio ašinès dalies (Drūkšių svita gretinama su Alvito svita, o Dysnos - su Šakių svita) ir Livonijos facijų zonos Jelgavos ịlinkiu (Moseno svitos Plungès pluoštas su Alvito svita, o tos pačios svitos Žarènų pluoštas su Šakių svita). Drūkšių-Paeknos svitos koreliuojamos su clingani, o Kaimynų - su linearis graptolitų zonomis. Paleontologiškai aprašyta nauja brachiopodų rūšis Thaerodonta notabile Pašk. sp. nov.

Raktažodžiai: Lietuvos facijų zona, ordovikas, litostratigrafija, koreliacija, brachiopodai 